\title{
Comparing Analgesic Efficacy of Regional Block Techniques After Laparoscopic Liver Resection: In Reply [Response to Letter]
}

\author{
RyungA Kang, Justin Sangwook Ko \\ Department of Anesthesiology and Pain Medicine, Samsung Medical Center, Sungkyunkwan University School of Medicine, Seoul, Korea
}

Correspondence: Justin Sangwook Ko, Department of Anesthesiology and Pain Medicine, Samsung Medical Center, Sungkyunkwan University School of Medicine, 8 I Irwon ro, Gangnam gu, Seoul, 0635I, Korea, Tel +82 2-34I0-2454, Fax +82 2-34I0-036I, Email jsko@skku.edu

\section{Dear editor}

We thank Dr. Nong He et al for their comments on our study. First, we agree that the distinction is important when designing, or interpreting the results of clinical trials. However, we disagree that the minimal clinically important difference (MCID) should dictate the effect size used in a sample size calculation for a clinical trial. ${ }^{1}$ The chosen effect size should be clinically or scientifically meaningful, but it need not be the MCID. ${ }^{2}$ In addition, the recommended MCIDs of $10 \mathrm{mg}$ IV morphine reduction for $24 \mathrm{~h}$ is for total hip arthroplasty or total knee arthroplasty, ${ }^{3}$ not for liver resection.

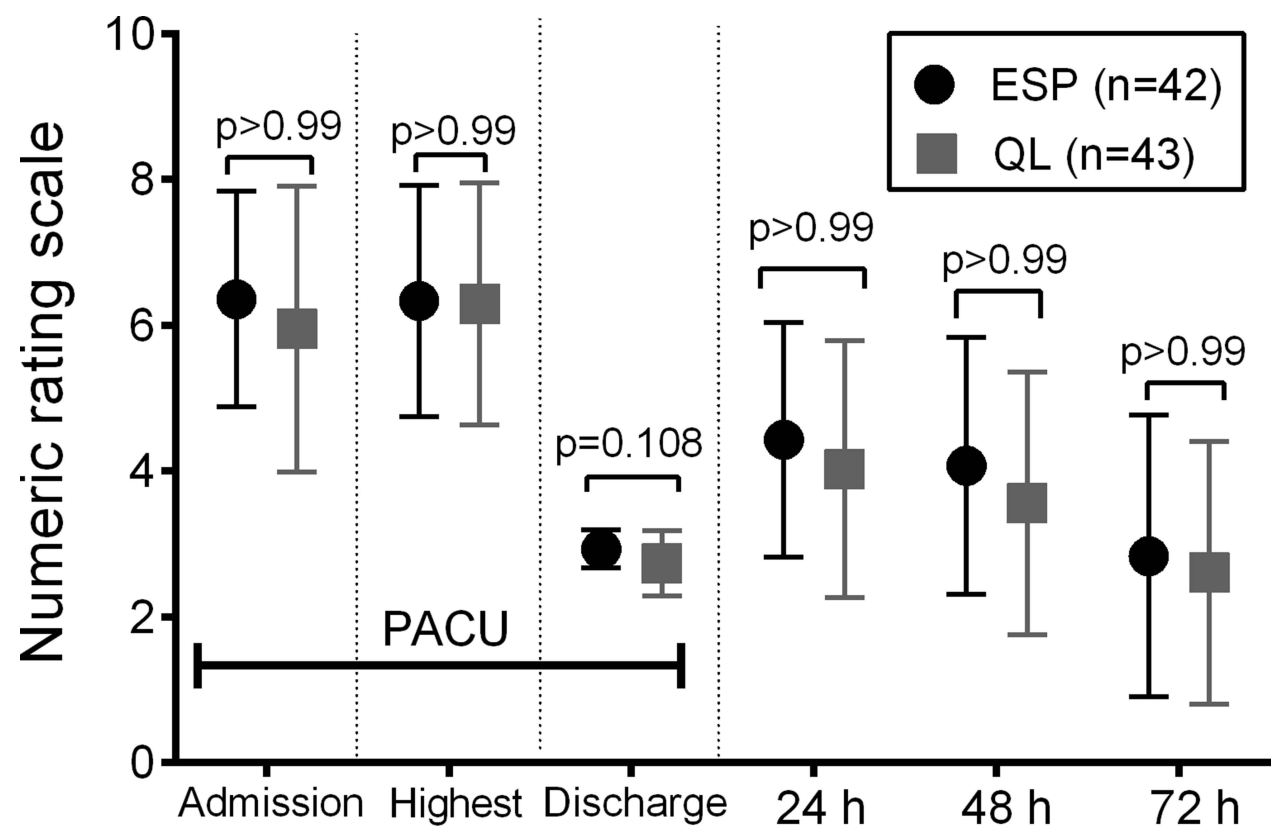

\section{Time points}

Figure 2 Numeric rating scale (NRS) scores at rest for the two groups within 72 hours postoperatively. P values result from a Bonferroni correction for multiple comparisons.

Notes: Reproduced from: Kang R, Lee S, Kim GS, et al. Comparison of Analgesic Efficacy of Erector Spinae Plane Block and Posterior Quadratus Lumborum Block in Laparoscopic Liver Resection: A Randomized Controlled Trial. J Pain Res. 2021;14:379I-3800. doi: 10.2I47/JPR.S343366. ${ }^{4}$ @ 202I Kang et al. Creative Commons Attribution - Non Commercial (unported, v3.0) License (http://creativecommons.org/licenses/by-nc/3.0/).

Abbreviations: ESP, erector spinae plane; QL, quadratus lumborum. 
Second, most patients complained of severe abdominal pain or discomfort when they were admitted to the PACU (ie, at emergence) which led to demands for additional opioid analgesics. So, the highest pain score was mostly detected at the time of PACU admission as shown in Figure $2,{ }^{4}$ and this severe pain may reflect significant visceral pain in addition to somatic pain. Although there is evidence that paravertebral or epidural spread can occur after facial plane blocks such as erector spinae plane block or quadratus lumborum block, it is not clear how consistently and to what extent this occurs, so it may not completely cover the visceral pain in our patients after hepatectomy. ${ }^{5}$

In our institution, postoperative pain management in the general ward was performed by the surgical team. We agree that postoperative pain management should be more refined to improve patient recovery. We also agree that repeated measurement of the QoR-15 questionnaire might be better to elucidate the quality of recovery between two peripheral nerve blocks. However, the QoR-15 score was the secondary outcome of this study, and we were more focused on the primary outcome (ie, cumulative opioid consumption) under the constraints such as limitations in time and manpower.

\section{Disclosure}

The authors report no conflicts of interest for this communication.

\section{References}

1. Myles PS, Myles DB. Conflating effect size and minimal clinically important difference. Comment on Br J Anaesth 2021; 126: 1029-37. Br J Anaesth. 2022;128(1):e1-e2. doi:10.1016/j.bja.2021.09.018

2. Walder B, Maillard J, Lubbeke A. Minimal clinically important difference: a novel approach to measure changes in outcome in perioperative Medicine. Eur J Anaesthesiol. 2015;32(2):77-78. doi:10.1097/EJA.0000000000000147

3. Laigaard J, Pedersen C, Ronsbo TN, Mathiesen O, Karlsen APH. Minimal clinically important differences in randomised clinical trials on pain management after total hip and knee arthroplasty: a systematic review. Br J Anaesth. 2021;126(5):1029-1037. doi:10.1016/j.bja.2021.01.021

4. Kang R, Lee S, Kim GS, et al. Comparison of Analgesic Efficacy of Erector Spinae Plane Block and Posterior Quadratus Lumborum Block in Laparoscopic Liver Resection: A Randomized Controlled Trial. J Pain Res. 2021;14:3791-3800. doi:10.2147/JPR.S343366

5. Kang R, Chin KJ, Gwak MS, et al. Bilateral single-injection erector spinae plane block versus intrathecal morphine for postoperative analgesia in living donor laparoscopic hepatectomy: a randomized non-inferiority trial. Reg Anesth Pain Med. 2019:rapm-2019-100902. doi:10.1136/rapm-2019100902

Dove Medical Press encourages responsible, free and frank academic debate. The content of the Journal of Pain Research 'letters to the editor' section does not necessarily represent the views of Dove Medical Press, its officers, agents, employees, related entities or the Journal of Pain Research editors. While all reasonable steps have been taken to confirm the content of each letter, Dove Medical Press accepts no liability in respect of the content of any letter, nor is it responsible for the content and accuracy of any letter to the editor.

Journal of Pain Research

\section{Dovepress}

\section{Publish your work in this journal}

The Journal of Pain Research is an international, peer reviewed, open access, online journal that welcomes laboratory and clinical findings in the fields of pain research and the prevention and management of pain. Original research, reviews, symposium reports, hypothesis formation and commentaries are all considered for publication. The manuscript management system is completely online and includes a very quick and fair peer-review system, which is all easy to use. Visit http://www.dovepress.com/testimonials.php to read real quotes from published authors.

Submit your manuscript here: https://www.dovepress.com/journal-of-pain-research-journal 